\title{
Groups and the Free Exercise Clause
}

\author{
Kenneth L. Karst†
}

Responding to Professor Stephen Carter's emphasis on the importance of a religious group's self-definition, Professor Karst proposes a perspective on the law of religious freedom in which both the state and claims to religious freedom are disaggregated into their various components. In such a perspective, he argues, one can find hope for the uses of state power to protect religious freedom. Pursuing Professor Carter's group-centered orientation, he concludes that proper interpretations of the religion clauses of the First Amendment will take account of the problem of group status domination.

When Professor Stephen Carter calls for a new conceptualization of religious freedom, ${ }^{1}$ he is speaking not to judges or lawyers, but to persons "of sincere and motivating [religious] behef," and especially to religious groups. "Perhaps," he says, "it is an error for religionists to conceive of the worship of God as a right because, in so doing, they reduce it to a thing that one needs a right in order to do."3 To file a legal claim to a right of religious freedom is to ask an arm of the state first to define your activity as religious and then to decide whether that freedom is compatible with the state's pressing needs. ${ }^{4}$ Religionists who go to law, he says, may be pressured to reshape their religions and their communities to make them acceptable to the state. To the extent that the religious do conform, they relinquish the power of religion to disrupt prevailing meanings and to subvert the state's temporal order. ${ }^{5}$ The only pure claim of religious freedom, then, lies in religious action, action that follows the dictates of one's faith. To take that claim to court is to put religion itself in harm's way.

Copyright $\odot 1999$ California Law Review, Inc.

$\dagger$ David G. Price and Dallas P. Price Professor of Law, University of California, Los Angeles.

1. See Stephen L. Carter, Religious Freedom as if Religion Matters: A Tribute to Justice Brennan, 87 CALIF. L. Rev. 1059 (1999).

2. Id. at 1085 .

3. Id. at 1086.

4. See id. at 1070-72.

5. Id. at 1071. 
Professor Carter's message is bleak: Legal remedies for the denial of religious freedom inevitably entail debilitating side effects, severely restricting religious freedom. Law, including constitutional law, is the exercise of state power, and the state cannot tolerate a religious freedom that matters. With legal remedies seen in this light, it is no wonder that Professor Carter resists offering a new prescription. I want to suggest a somewhat different perspective on the constitutional law of religious freedom, one in which the prospect may seem more congenial, and less threatening, to religious freedom. In this perspective, both the state and religious freedom can be seen, not as singular and invariably opposed, but as disaggregated and, in their diverse forms, ranged across a spectrum that runs from opposition to mutual reinforcement.

Neither Professor Carter's perspective nor my own will affect the flow of religious freedom claims into our courtrooms. For as long as anyone can foresee, governmental action will continue to impinge on the religious freedom of individuals and groups, putting believers to the dilemma illuminated by Professor Carter. Although he does not counsel the faithful to engage in civil disobedience, neither does he counsel a saintly passivity when the state intrudes on their religious practices. His warning notwithstanding, surely a great many individuals and groups will continue to resort to law, claiming the freedom of religion as their right under the Umited States Constitution. In these cases, as Professor Carter says, judges will have no option but to translate issues of religious freedom into issues of constitutional doctrine. ${ }^{6}$

Here I want to do some translating of my own. Despite his disclaimer to the contrary, ${ }^{7}$ Professor Carter's emphasis on a religious group's selfdefinition evokes inquiries that can inform the legal analysis of rights, and I do mean rights under the Free Exercise Clause. My effort may not be entirely uncongenial to Professor Carter. His elegy, for all its gloom, is dedicated to Justice Brennan, a steadfast optimist who believed in the capacity of the judiciary to make positive contributions to human freedom.

I

\section{Disaggregating the STate}

If we agree with Justice Brennan that our courts have the capacity to stand as the protectors of constitutional liberty, we begin what I think is a necessary process: disaggregating the abstraction of the state into its many and variegated components. If the state legislature is government, so is Oregon's Employment Division, ${ }^{8}$ the warden who makes Muslim prisoners

6. See id. at 1073 .

7. See id. at 1085.

8. See Employment Div., Dep't of Human Resources v. Smith, 494 U.S. 872, 890 (1990). 
work on Fridays, ${ }^{9}$ and the Hialeah city council. ${ }^{10}$ If the Congress is government, so is the engineer who lays out roads for the Forest Service, ${ }^{11}$ the Air Force officer who disciplines another officer for wearing a yarmulke with his uniform, ${ }^{12}$ and the IRS official who thinks the Church of Scientology is running a business. ${ }^{13}$

Professor Carter's warning to the faithful emphasizes that the state also includes the Supreme Court Justice who may learn, from a case record, about the doings of the other officials I have listed. But I want to insist-and I wish Justice Brennan could be here to lend his support-that American courts, far froin being just another part of an undifferentiated lump of sovereignty called the state, have a task, a solemn responsibility under the Constitution, that differentiates them from those other officials. I concede that the Supreme Court abdicated this responsibility for independent review under the Free Exercise Clause in the peyote case, Employment Division, Department of Human Resources v. Smith, ${ }^{14}$ and even before Smith a majority of the Court was insensitive to claims of religious liberty (despite several spirited dissents by Justice Brennan that deserve to be anthologized). But it appears entirely possible-if you will permit ine a crude counting of votes - that neither Smith nor its predecessor decisions of the 1980 s will be the last judicial word on this painful subject. If a new majority of the Court should emerge from the statism of the Smith rule, the separateness of the judiciary from the other branches of government will also become visible.

Beyond the Justices, even beyond the whole court system, stand other officers of government who - at least sometimes - can be prevailed upon to validate claims of religious freedom. After the Supreme Court upheld the discipline of a Jewish officer for wearing the yarmulke, ${ }^{15}$ Congress stepped in to allow service personnel to wear "conservative" religious regalia with their uniforms. ${ }^{16}$ Soon after the Supreme Court upheld Oregon's deinal of unemployinent compensation to men fired for taking peyote during a ceremony of the Native American Church, ${ }^{17}$ the Oregon

9. See O'Lone v. Estate of Shabazz, 482 U.S. 342 (1987).

10. See Church of the Lukumi Babalu Aye, Inc. v. City of Hialeah, 508 U.S. 520 (1993).

11. See Lyng v. Northwest Indian Cemetery Protective Ass'n, 485 U.S. 439 (1988).

12. See Goldman v. Weinberger, 475 U.S. 503 (1986).

13. See Hernández v. Commissioner, 490 U.S. 680, 689 (1989) (upholding the IRS's determination that certain contributions to the Church were really payment for various courses of instruction). A few years later, in the face of criticism, the IRS reversed this position. See Rev. Rul. 9373, 1993-2 C.B. 75, 1993-34 I.R.B. 7 (stating in full, "Revenue Ruling 78-189, 1978-1 C.B., is obsoleted").

14. 494 U.S. at 890 (upholding Oregon's denial of unemployment benefits to persons dismissed from their jobs for taking peyote in a ceremony of the Native American Church).

15. See Goldman, 475 U.S. at 503.

16. See National Defense Authorization Act for the Fiscal Years 1988 and 1989, Pub. L. No. 100-180, 101 Stat. 1019, 1086-87 (1987) (codified at 10 U.S.C. $\$ 774$ (1994)) .

17. See Smith, 494 U.S. at 890 . 
legislature enacted a religious exception to the state's prohibition on taking peyote. ${ }^{18}$ The supporters of measures like these normally say they are vindicating constitutional rights.

The state is no monolith. A claim of constitutional right can persuade a zoning board not to apply a landmark preservation ordinance in a manner preventing a church from moving its altar; it can persuade a motor vehicles department to allow a motorist to have a driver's license even though he objects, on religious grounds, to identification by a Social Security number; or it can persuade a trial judge to set aside an inflated damages award against a religious group sued by angry parents for "brainwashing" their child. In other words, if we disaggregate the state, we can identify a great many opportunities-not just in courtrooms-for successful deployment of the language of constitutional rights to religious freedom.

Still, the courtroom does seem (to say the least) an appropriate forum for claiming the freedoin of religion as a constitutional right. Until 1990 it was realistic for a claimant to expect the judiciary to take such a claim seriously. Justice Brennan had led the way; his opinion in Sherbert $v$. Verner $^{19}$ is rightly called a landmark. That opimon insisted that a state law had no constitutional authority to disadvantage someone for behavior required by her religion, absent a showing that the law was necessary to serve a compelling state interest. A number of the cases discussed by Professor Carter were decided during the era of Sherbert, and although the Court gave the compelling state imterest requirement teeth in some of those cases,${ }^{20} \mathrm{im}$ most of the cases the Court gave that requirement lip service and little more. ${ }^{21}$ The deficiency in the latter cases was not some fatal flaw in the Free Exercise Clause, but the failure of shifting majorities to follow the dictates of the Sherbert doctrine. Sherbert's value as precedent was largely washed away in a tidal wave of formal neutrality in the 1990 peyote case, ${ }^{22}$ but its value may well re-emerge when a new majority of the Supreme Court appreciates what has been lost.

18. See Act of June 24, 1991, ch. 329, 1991 Or. Laws 329 (codified at Or. Rev. STaT. $\$ 475.992$ (1997)).

19. 374 U.S. 398,410 (1963) (holding that the state could not deny unemployment benefits to a Seventh Day Adventist unwilling to work on Saturday, her Sabbath).

20. The most celebrated is Wisconsin v. Yoder, 406 U.S. 205 (1972), cited by Professor Carter, supra note 1 , at 1078 n.39.

21. See, e.g., Lyng v. Northwest Indian Cemetery Protective Ass'n, 485 U.S. 439 (1988), cited in Carter, supra note 1, at 1063 n.5; Bowen v. Roy, 476 U.S. 693 (1986), cited in Carter, supra note 1, at 1070 n.22; Hernández v. Commissioner, 490 U.S. 680 (1989), cited in Carter, supra note 1, 1086 n.60.

22. See Smith, 494 U.S. at 883-85. 
II

\section{Disaggregating Claims of Religious Freedoms (Herein of MUltiple Religions and of Group STatus Domination)}

Professor Carter did not make Justice Brennan the hero of his tale on the basis of Sherbert $v$. Verner. Instead, Justice Brennan is put in the spotlight for some lesser-known remarks a quarter century later. In the passages highlighted by Professor Carter, Justice Brennan affirms that religious freedom demands ample autonomy for religious communities in drawing the boundaries of their membership. ${ }^{23}$

For Professor Carter, recognition of this autonomy implies strong deference to a religious group's definitions of itself and its mission. "And," he adds, "that is what the theory I have been discussing requires, too.....24 As Professor Carter makes clear, his is not a theory about constitutional rights; it is a theory about religion. ${ }^{25}$ The theory first posits the importance of a group in defiming religious meanings, and, second, specifies the dangers to this self-definition when the group claims its religious freedom as a constitutional right. ${ }^{26}$ In contrast, when Justice Brennan recognized the importance of a religious group's self-definition to religious freedom, he was not advising the faithful, but was speaking to judges in the language of constitutional law. Such a group-centered compass bearing orients the courts against the grain of most commentary about the Free Exercise Clause, which has assumed that the clause protects individual liberty and nothing more. ${ }^{27}$ This imdividualist orientation omits any consideration of group status domination-a group-oriented problem that has been a focus for constitutional theory from The Federalist ${ }^{28}$ to "footnote $4 " 29$ to the great opinions that revived the principle of equal citizenship im the civil rights era. ${ }^{30}$ Any exploration of the problem of status domination in the context of American religion will begin in the disaggregation of religions and of claims to religious freedom: recognition

23. See Carter, supra note 1, at 1077 (referring to Justice Brennan's concurring opinion in Corporation of the Presiding Bishop of the Church of Jesus Christ of Latter-Day Saints v. Amos, 483 U.S. 327 (1987)).

24. Id. at 1077.

25. See id. at 1059 and passim.

26. See id. at 1073-77.

27. See, e.g., Michael W. McConnell, Free Exercise Revisionism and the Smith Decision, $57 \mathrm{U}$. CHI. L. Rev. 1109 (1990); Michael A. Paulsen, Religion, Equality, and the Constitution: An Equal Protection Approach to Establishment Clause Adjndication, 61 Notre DAME L. REv. 311, 313 (1986).

28. The Federalist Nos. 10, 51 (J. Madison).

29. United States v. Carolene Prods. Co., 304 U:S. 144, 152 n.4 (1938).

30. See Robert M. Cover, The Origins of Judicial Activism in the Protection of Minorities, 91 YALE L.J. 1287, 1297-1300 (1982) (discussing the group-centered definition of "minorities" during and after World War M). 
that the diversity of our religions has generated persistent contests among religious groups for status dominance. ${ }^{31}$

Status domination is a group experience for both winners and losers, and it is a zero-sum game. One group achieves status dominance at the expense of other groups whose members are marginalized as outsiders, sometimes stigmatized, and sometimes effectively excluded from equal citizenship. The "status harm"32 thus suffered by individuals is imposed on them by virtue of their group membership. The use of the political process to promote the status of particular religious groups is familiar in various contexts of Establishment Clause litigation, from official Nativity scenes to prayer in the public schools. ${ }^{33}$ However-and here the prevailing individual-liberty theory misses the point-the problem of group status domination miplicates the Free Exercise Clause as well.

The problem tends to arise most acutely in local communities. At the level of the national government, however, there is little political push for what Professor Carter calls governmental "domestication" of religion, for no religious group comes close to posing a threat to "upend" the state. ${ }^{34}$ The classically Madisonian reason for this stability is the multitude of sects across the country. ${ }^{35}$ Professor Carter recognizes this multiplicity when he moves beyond his general theory counterposing religion and the state, illustrating his point with live examples. He does disaggregate the concept of religion when he comments that "big religions win and small ones lose." expected from legislators in the aftermath of Smith. ${ }^{37}$

Of course, froin time to time, little religious groups do win in court. The Jehovah's Witnesses won fairly regularly half a century ago, ${ }^{38}$ and

31. For example, Professor Carter discusses Protestant status dominance over Catholics in the context of 19th century public education. See Carter, supra note 1, at 1080-81.

32. Owen M. Fiss, Groups and the Equal Protection Clause, 5 PHiL. \& PuB. Afr. 107, 157 (1976).

33. See, e.g., Lee v. Weisman, 505 U.S. 577, 590-99 (1992) (holding unconstitutional schoolsponsored prayer in public school graduation); Lynch v. Donnelly, 465 U.S. 668, 687-89 (1984) (O'Connor, J., concurring) (upholding city-sponsored Nativity scene in its Christmas display). See generally Kenneth L. Karst, The First Amendment, the Politics of Religion and the Symbols of Government, 27 HARv. C.R.-C.L. L. REv. 503 (1992).

34. Carter, supra note 1 , at 1060.

35. See The Federal1st No. 10 (James Madison).

36. Carter, supra note 1 , at 1063.

37. Employment Div., Dep't of Human Resources v. Smith, 494 U.S. 872 (1990). And, as well, in the aftermath of the demise of the Religious Freedorn Restoration Act, accomplished by the Supreme Court in City of Boerne v. Flores, 117 S. Ct. 2157 (1997).

38. See, e.g., West Virginia State Bd. of Educ. v. Barnette, 319 U.S. 624 (1943) (holding unconstitutional a requirement that public school children salute the American flag in violation of thcir religious belief); Martin v. City of Struthers, 319 U.S. 141 (1943) (vacating conviction for circulating literature door to door, in violation of local ordinance); Lovell v. City of Griffin, 303 U.S. 444 (1938) (reversing conviction of Jehovah's Witness for circulating literature in violation of publie ordinance). 
today, even after Smith, a small religion can win if it persuades the courts that it has been "targeted" for unfavorable treatment. ${ }^{39}$ But actors in the legislative process constantly think in terms of constituencies, and that means groups, the bigger the better. Sometimes, we have seen, relatively small religious groups can mobilize legislative majorities on their behalf. ${ }^{40}$ This sort of relief usually comes when the accommodation of a religious practice causes no serious harm to any other group, nor to any state policy widely seen as important. But when a legislative accommodation benefits one religious group at another group's expense, it is a good bet that the legislature has been enlisted to aid one of the players in a group-centered, zero-sum game of status domination.

For example, consider what happened to a bill in the Minnesota legislature that required religious groups to register and to report their sources of income. ${ }^{41}$ At the urging of the Roman Catholic archdiocese, the legislature amended this bill to exempt any group that was mainly supported by members' contributions. The bill that passed the legislature required registration and reporting only by groups that received more than half their support from solicitation. ${ }^{42}$ The latter pattern characterized the Unification Church-as the legislators fully understood. ${ }^{43}$ The Supreme Court also recogmized this differential treatment and held the law invalid, announcing a strong presumption of unconstitutionality whenever legislators purposefully discriminate among religions. ${ }^{44}$ The author of the Court's opinion, not surprisingly, was Justice Brennan. ${ }^{45}$

The Minnesota case was easy. But the problem of group status domination is not limited to the favoring of one religious group or the "targeting" of a disfavored group. Many claims under the Free Exercise Clause result from governmental regulations written with no conscious thought of religion at all. The Air Force's uniform regulation is one example; the Social Security system's use of identification numbers is another. Surely the government actors who adopted those rules were simply indifferent to any possible effects on religious liberty. But suppose that a large religious group in Anierica-say, the Southern

Many of the Witnesses' victories were explained on the grounds of freedom of speech, but often that ground was coupled with a free exercise ground.

39. See Church of the Lukumi Babalu Aye, Inc. v. City of Hialeah, 508 U.S. 520,535 (1993). Justice Kennedy's opinion for the Court in this case gives some hope that the "targeting" idea can be used as a way of tunneling under the Smith barrier. See Kenneth L. Karst, Religious Freedom and Equal Citizenship: Reflections on Lukumi, 69 TUL. L. REv. 335 (1994).

40. See supra text accompanying note 18.

41. See Larson v. Valente, 456 U.S. 228, 231 (1982).

42. See id at 231-32.

43. See id. at 255 (quoting legislator's remark: 'I'm not sure why we're so hot to regulate the Moonies anyway").

44. See id. at 246.

45. This deeision is another illustration of the analytical utility of disaggregating the state. See supra text at 1094-96. 
Baptists-historically required the wearing of a small head covering, or historically regarded any systematic program to identify people by number as the Mark of the Beast. It takes no stretch to imagine that the regulations specifying military uniforms and the use of Social Security numbers might have included religious exemptions from the time of their adoption, just as modern liquor prohibition laws have exempted the taking of sacramental wine. The people who make laws and regulations are almost never indifferent to the interests of any influential group. ${ }^{46}$

A prominent example of this influence is the exemption of religious groups from Title VII's prohibition on religious discrimination in einployinent. This exemption provided the occasion for Justice Brennan's comments in the Amos case,${ }^{47}$ celebrated by Professor Carter ${ }^{48}$ Justice Brennan rightly einphasizes the importance of a rehigious group's power of self-defimition. Here we have another nice illustration of the need to disaggregate the state when we think about the freedom of religion. After all, it was Congress that "carv[ed] out a sphere" of authority for the religious group, ${ }^{49}$ the Latter-Day Saints had the legislature on their side. The Supreine Court's inajority dealt with the case as a challenge under the Establishinent Clause, and upheld the religious exemption. In another perspective-one that disaggregates claims of religious freedom-the Amos case presented a clash of religious liberties. Justice Brennan saw the case in this light: If the Church was claiming religious freedom, so was the einployee who lost his job because he was not a inember of the Church. ${ }^{50}$ It nay not be news, but it is still worth remembering: Sometimes, expanding religious freedoin for some people will limit religious freedoin for others. An across-the-board exemption of religious employers from Title VII's ban on religious discrimination does not seem likely to contribute to the status subordination of any group, and I have no quarrel with the result in the Amos case or with Justice Brennan's gloss.

Still, there will be cases in which granting a religious exemption will have grave consequences for group status domination, and there I would draw the line. One such case was the Supreme Court's 1983 decision in

46. Nowadays, religious groups are sophisticated practitioners of the political arts, from phone banks to direct mail solicitation to the hiring of professional lobbyists. On national lobbies, see ALLEN D. Hertzke, Representing God in Washington (1988). These groups' support is courted by politicians from sea to shining sea. An example is the recent overture by California's (now former) governor to the Christian Coalition. See Dave Lesher, Wilson Offers Abortion Truce to Christian Coalition, L.A. TIMEs, Nov. 9, 1997, at A3. The groups' legislative objectives are, of course, far more ambitious than the securing of rehigious freedom by means of exemptions from general regulatory laws.

47. Corporation of the Presiding Bishop of the Church of Jesus Christ of Latter-Day Saints v. Amos, 483 U.S. 327, 341 (1987) (upholding exemption for religious groups from religious discrimination provisious of Title VII).

48. See Carter, supra note 1 at 1076.

49. Id at 1066 .

50. Justice Brennan, as we know, could easily imagine a religion of one member. See Frazee v. Illinois Dep't of Employment Sec., 489 U.S. 829 (1989). 
Bob Jones University v. United States, ${ }^{51}$ mentioned by Professor Carter as an example of state pressure on a religious group..$^{52}$ The Internal Revenue Service had denied "charitable" tax-exempt status to two religious educational imstitutions: to Bob Jones University because it prohibited interracial dating or marriage among its students, and to Goldsboro Christian School because it limited enrollment to Caucasians. The Court upheld both denials of exempt status, dealing with the schools' claims under the Free Exercise Clause in a slapdash way. ${ }^{53}$ Of conrse, under the principle of formal neutrality of the Smith opinion ${ }^{54}-$ a principle that threatens to reduce religious liberty to a constitutional trifle ${ }^{55}$-the IRS rulings in Bob Jones University likely would not be seriously challenged today. But let us imagine that the Supreme Court will revive the Free Exercise Clause as a generous guarantee of substantive neutrality-what Professor Carter calls "accommodationism." ${ }^{\text {"In }}$ In that event, how slould another case like Bob Jones University be decided?

Some critics of the decision treat the denial of exemptions in this case as the economic equivalent of a tax or a fine, ${ }^{57}$ and I agree. But that characterization still leaves the courts with a dilemma. Even assuming that the Supreme Court will restore a principle of substantive neutrality, there is no obvious baseline of neutrality from which to proceed. Those who believe that God commands segregation will argue that the proper baseline is "tax exemption for religious and educational institutions," and the IRS will argue for a baseline of "no tax exemption for racial discrimination." Both of these arguments resonate with constitutional values of a high order. Are the courts just stuck on dead center?

I think not. For the Court to hold that the Free Exercise Clause exempts a racially segregated school from the IRS's otherwise valid nondiscrimination ruling would imply a similar religious exemption from Title VI of the Civil Rights Act of 1964, which denies federal subsidies to institutions that practice racial discrimination. Standing in line behind Goldsboro Christian School would be hundreds of religiously affiliated "segregation academies" that sprang up in the wake of desegregation decrees of the 1960s and 1970s. If the demial of a tax exemption is the functional equivalent of a penalty, the grant of an exemption is the functional equivalent of a subsidy. If the Constitution forbids Mississippi from subsidizing segregation academies by supplying free textbooks, ${ }^{58}$ the

\footnotetext{
51. 461 U.S. 574 (1983).

52. See Carter, supra note 1 , at $1068,1074$.

53. These paragraphs are adapted from a fuller discussion in Karst, supra note 39, at 365-71.

54. Employment Div., Dep't of Human Resources v. Smith, 494 U.S. 872, 890 (1990).

55. See supra text accompanying notes 14 and 22.

56. Carter, supra note 1 , at 1062 .

57. See Paulsen, supra note 27 , at 365 .

58. See Norwood v. Harrison, 413 U.S. 455, 470-71 (1973).
} 
Constitution should not compel the United States to subsidize them through tax exemptions.

As Professor Carter and others have noted, in this context the chief claim of religious freedom goes to the segregated schools' power of selfdefinition..$^{59}$ An analysis that seeks to disaggregate claims of religious freedom will offer little help here. It is awkward even to formulate a competing religious freedom interest-say, the interest of a Bob Jones student whose religious views generally parallel those of the University, except that he wishes to marry a woman whose racial identity differs from his own. Still, the disaggregation perspective does teach a more general lesson that would be useful in a hypothetical Bob Jones University rerun: to be alert to the risk that validating one group's claim to religious liberty may work a status harm to another group. That risk was presented in the 1983 case, even though the Supreme Court did not discuss it.

Consider again the issue of a religious exemption for racially segregated religious schools. When we view this issue through the prism of group status domination, the argument for reaffirming the result in $B o b$ Jones University becomes even more compelling. Social status is centered on intangibles such as "prestige and honor," or "approval, respect, admiration"-or, indeed, the opposites of these qualities, from disapproval to dishonor. ${ }^{60}$ Central to any group's status is the expression of just those qualities. Indeed, a contest over group status is, in great measure, a contest for expressive dominance. In the "culture wars" of the past generation, inuch of the contest has been carried on in the political arena, where voters have been mobilized by promises centered on the expressive power of government. The typical message has taken this form: The election of Candidate $X$ will give right-thinking people control over the government's power to declare that the values of Group A are the official values of America. The subjects of race and religion have played major roles in these contests for expressive dominance. ${ }^{61}$ A federal tax exemption to a segregated or openly racist academy would place the government's own moral support behind the status subordination of a racial group-a result directly contrary to an important expressive function of Title VI. In this contest for expressive dominance, neutrality is not possible; Congress can constitutionally place the moral weight of the United States governinent on the side of racial equality.

59. See Carter, supra note 1, at 1067-68; McConnell, supra note 27, at 1146 . .

60. See, e.g., J. M. Balkin, The Constitution of Status, 106 YALE L.J. 2313, 2321 (1997).

61. I discussed this subject at book length in LAW's Promise, LAW's EXPRESSION: VISIONS of POWER IN THE POLITICS OF RACE, GENDER, AND RELIGION (1993). 


\section{III \\ Conclusion}

By highlighting the crucial role of religious groups in preserving religious freedom, Professor Carter illuminates inore than one path to freedom. On the path that judges must walk, a concern for the problem of group status dominance will help our courts to do justice. We can even pray that their version of justice will be welcome in higher places. Referring to the Bob Jones University case, Professor Carter remarks that to the extent that "Southern Baptists yield on racism ... we can sit and congratulate ourselves and insist that state pressure has made [the University] morally better," but, he asks, will this pressure have "helped move [this faith] to a truer understanding of the will of God?"62 He hopes the answer is "Yes"- and so do I. If an arm of the state such as the Internal Revenue Service seems to us to be an unlikely instrument of revelation, perhaps we should recall the words of an old hymn: "God moves in a mysterious way/ His wonders to perform." ${ }^{63}$

62. Carter, supra note 1 , at 1085.

63. William Cowper, Light Shining Out of Darkness, in OLNEY HyMNs 35 (1779). We can also take some comfort from a former President of the Church of Jesus Christ of Latter-Day Saints, who received a revelation that the Church should no longer restrict black people from full participation in the Church's ministry. I hope it is not disrespectful to notice that the revelation arrived during the latter days of the American civil rights movement. It may well be that God wants us to educate each other in decency. 
